\title{
ETHICAL WISDOM AND PHILOSOPHICAL JUDGMENT IN AMISH TRIPATHI'S THE SHIVA TRILOGY.
}

\section{Mr. Parthivkumar K. Patel}

\begin{abstract}
While the study discusses the issues of liberation, emancipation, equal rights and womanhood, it gives significance to humans and their relations, as self does not exist in seclusion. While enriching the differences, this fiction strengthens the cultural integrity of India. Through recreation, "The Shiva Trilogy" becomes the living inspirational scripture capable of providing spiritual direction to the present world. morover paper is going explain new writing style of 21 ts century writers. This research starts with the question that why $21^{\text {st }}$ century Indian writer suddenly divert their attention towards mythology. This era is a known as science; people are not that much believing in religion, mythology even good and evil. This research is pure philosophical, a research paper on what is evil and that got converted into an adventure convey that philosophy. And if you have to write an adventure to convey a philosophy on evil, well then the best hero is the destroyer of evil himself, Lord Shiva.
\end{abstract}

\section{Introduction:}

In a society bereft of humanity, human values there is need of this great philosophy and understanding of human nature and society. Vasudeva's words may be examined under Bohr's principle of complementarily. According to him every entity in Nature posses pairs of contradictory characters such as corpuscular property and wave property. The contradictory characters are not exclusive of each other, but are complementary. For an integral comprehension of the entity as a whole, it is necessary to know both the contradictory characters. 
There is evil in every single one of us. Exactly, There is a god in every single one of us. And there is evil in every single one of us. The true battle between good and evil is fought within. And the great evil connects itself to the evil within us. Is that why people get attached to it? I believe that when you discover the great evil of our times, you will not need any explanation about how it attaches itself so deeply to us. (111-113 the Secret of the Nagas) The war Shiva wages in the Trilogy is not the war against any person. But it is against the evil possible in anybody. After meeting the grown up Ganesha and knowing the matter of Meluhans' practice of leaving the children born with deformities in the river, Shiva expresses his doubt, 'I suspect that Chandandhvaj did not die naturally', 'My Lord!' Nandi spoke up in shock. 'But that cannot be true. That is a crime. No Suryavanshi ruler will ever stoop so low.' 'It is just a feeling that I have. Remember nobody is good or bad. They are either strong or weak. Strong people stick to their morals, no matter what the trials and tribulations. Weak people, many a times, do not even realize how low they have sunk.' (315 The Secret of Nagas) 'Because desire creates attachment.

Attachment to this world. And, when you don't get what you want or get what you don't want, it leads to suffering. This leads to anger. And that to violence and wars, 'Which finally results in destruction.' 'So if you want to avoid destruction and suffering, you should control your desires, right?' asked the teacher. 'Give up Maya, the illusion of this world?' 'But the Rig Veda, one of our main sources of philosophy', continued teacher 'says that in the beginning of time, there was nothing except darkness and a primordial flood. Then out of this darkness, desire was born. Desire was the primal seed, the germ of creation. And from here, we all know that the Prajapati, the Lord of the Creatures, created the Universe and everything in it. So in a sense, desire is the root of creation as well.' 'How can desire be the source of creation as well as destruction?' 'Is it safe to assume that anything that has been created has to be destroyed at some point in time? 'Yes', answered a student. 'That is the purpose of desire. It is the beginning and the end of a journey. Without desire, there is nothing.' (381,382 The Secret of Nagas) This ideology of good and bad in person is what modern psychology proves of. The skill of Amish in spreading thread by thread the highly philosophical matters like, good and bad, desire, evil before the readers and his knowledge is praise worthy. Even for a common reader these ideologies are legible.

\section{Vikarma and Maika System:}




\section{Parthivkumar Patel / Page 17- 25}

Shiva finds some grossly unfair practices in the nearly perfect society. 'Vikarma people, my Lord,' said Nandi sighing deeply 'are people who have been punished in this birth for the sins of their previous birth. Hence they have to live this life out with dignity and tolerate their present sufferings with grace. This is the only way they can wipe their karma clean of the sins of their previous births. Vikarma men have their own order and women have their own order.' Shiva questions, 'But tell me one thing. Who decides that the Vikarma people had committed sins in their previous birth?' 'Their own karma, my lord,' for example if a woman gives birth to a still born child, why would she be punished thus unless she had committed some terrible sin in her previous birth? Or if a man suddenly contracts an incurable disease and gets paralyzed, why would it happen to him unless the universe was penalizing him for the sins of his previous life?' 'That sounds pretty ridiculous to me.' Later at Mohan Jo Daro Shiva questions Pundit? 'How can anyone be sure that these people committed sins in their previous birth? And that their present sufferings are a result of that? In the dialogue Nandi, like all Meluhans looks so ignorant. Shiva changes the belief of Meluhans and marries Sati, who was believed to be vikarma as her child was still born and her husband also died at the same time. Shiva says of the vikarma system, 'It would only lead to a progressive increase in pent-up anger' (p211Meluha). He even enrolls some vikarmas into his army. Of Maika system the Pundit at Mohan Jo Daro says, 'If we believe that flexibility is a key to successful society, then the Maika system is designed to achieve it in practice. No child knows what the professions of his birth-parents are. He is independent to pursue what his natural talent inspires him to do.' Shiva is not with Maika system also. $\mathrm{He}$ questions, 'But this is about flexibility. What about stability?' This is one step in his war against evil. Breaking from Ram's rules as the changed time demanded Shiva deconstructed the life system.

Rudra and Shiva: According to the novel, Rudra is Lord Shiva's ancestor. And Lord Rudra was called as Shiva with love by his mother, which others didn't know. Even Shiva was surprised knowing this by his uncle when he goes to bring Brahmastra from Pariha (today's Iran). But a great scholar Dr. Shankarrao Baladeekshit Joshi has interpreted the concept of Shiva differently. For him Rudra is Aryan word for Shiva the Dravidian word. Both the words mean red, shining, auspicious, and golden. From 'Shin' Shi(n)va, chin, chen, ken words have taken shape. 


\section{Sura and Asura concepts:}

From the following dialogues two different ideologies on Sura and Asura concepts of Parihans and Meluhans are visible. Gopal glanced at Shiva conspiratorially. 'Before you answer, know this that in the old Parihan language, there was no place for the production and perception of the phonetic sound "s". It either became "sh" or "h". So, what do you think they called their gods?' Shiva frowned, making a wild guess, 'Ahuras?' 'Yes, Ahuras'. 'Good Lord! What were their demons called then?' 'Daevas'.'By the exact opposite of the Indian patheon. We call gods Devas and demons Asuras.' Shiva smiled slightly. 'They're different, but they're not evil'.

'The Asuraas took refuge here? Asked Shiva. Still in shock. "Yes, Lord Rudra himself brought the few surviving Asura leaders to Pariha. Others, who were in hiding, were led out of india by the Vayuputras. Some Asuras went farthest, he found that a few of the Asuras were not detached enough to become members of the Vayuputra tribe. They were allowed to live in Pariha as refugees.' (371 The Oath of the Vayuputras) Gopal glanced at Shiva. Our phonetic sound "s" became "sh" or "h" in Parihan language. There is no place for the production and perception of the phonetic sound "s". They called their gods 'Ahuras'. Their demons were called Daevas.

\section{Women Engendered:}

So many women characters in the novel are warriors of no less valor and strength of men's. The first glimpse of Sati in the first of the Trilogy occurs when Shiva meets her outside the temple. She rode in on a chariot, guiding the horses expertly into the courtyard, while a lady companion by her side held on to the railings. She dismounted the chariot with an air of confidence. It was a calm confidence which had not covered the ugly distance towards arrogance. Her walk was dignified. Stately enough to let a beholder know that she was detached, but not cold. (48 The Immortals of Meluha) Sati comes out of the temple and questions staring Shiva 'Excuse me, is there a problem?' here we can see her boldness in questioning a stranger. That moment Shiva was alerted by a quick movement from the cucumber seller. Shiva turned to see him pulling out a sword as he tossed his shawl aside. The shepherd and the man next to the chariot also stood poised in traditional fighter positions with their swords drawn.

In a flash Shiva drew his sword and stretched out his left hand protectively, to pull the object of his protective hand, reached into the folds of her Angvastram and drew out her own 
sword. Surprised Shiva flashed her quick, admiring smile. Her eyes flashed right back, acknowledging the unexpected yet providential partnership. Shiva and the lady stood back to back in a defensive partner position, covering all the directions of any possible attack. (50 The Immortals of Meluha) Here in Amish's portrayal Sati is not less to Shiva in valor. Her last fight in her life was with Swuth. Swuth whirled around, stunned. Sati was up on one knee. She was breathing rapidly, forcing some strength into her debilitated body. She had dug her sword into the ground and her right hand was on its hilt as she tried to use the leverage to push herself up. She failed, took quick breaths, Swuth stared at Sati, dumbstruck. She was completely soaked in her own blood, there were cavernous wounds all over her body, and her hands were shivering with the tremendous pain she was in. her soul must know that death was just minutes away. Tears sprang into Swuth's eyes as his heart felt immeasurably heavy. This indeed was his final kill, and removed his mask. Unlike all his other weapons, this sword was marked. It was marked with the name of their God, Aten. Below that had been inscribed the name of the devotee, Swuth. Swuth bowed low before Sati, and Swuth went down on one knee. He had to give Sati an honorable death. (476-478 the Oath of the Vayuputras) Throughout the Trilogy Sati's decisions, stances of her valor are so realistically pictured by Amish that for his impartial sketches of women characters is convincing. The first lady Shiva meets on Meluhan's land is Ayurvati. "Welcome to Meluha. I am Ayurvati, your designated doctor. My nurses and I will be at your assistance for the time that you are in these quarters." We see Ayurvati's marvelous treatment which saves Shiva and Sati in different situations. Those were the days when woman was as free as men to learn skills and work. The next important woman of strength in the Meluha is Kanakhala. Smiling politely, Daksha asked, 'May I introduce my most important aides? This is my prime minister, Kanakhala. She takes care of the administrative, revenue and protocol matters.' (67 The Immortals of Meluha) Both Sati and Kanakhala had chance of choice. But they choose the path to truth, which lead them to their death in fighting for the great cause. Anandamayi takes decision of staying with her husband Parvateshwar even in high risk of life, even in situation of standing against her brother. Tara a scientist helped in the production of Somras as well as daiviastras like, Pashupatiastra and Brahmastra.

\section{Ardha Narishwar philosophy:}


'So the key point is that we humans are nothing individually,' said the Pandit. 'Our power flows from all of us. From the way all of us live together.' But if you actually distil the way people live, there are only two ways: The Masculine and the Feminine.' "The Masculine way of life is "life by laws". Laws that could be made by a great leader, perhaps a Vishnu like Lord Ram. Or laws that come down from a religious tradition. Or collective laws decreed by the people themselves. But the masculine way is very clear. Laws are unchangeable and they must be followed rigidly. There is no room for ambiguity. Life is predictable because the populace will always do what has been ordained. Meluha is perfect example of such a way of life. It is obvious, therefore, why the people of this way of life live by the code of Truth, Duty and Honor. Since that's what they need to be successful in this system. 'and the feminine?'

"The feminine way of life is "life by probabilities". There are no absolutes. No black or white. People don't act as per some preordained law, but based on probabilities of different outcomes perceived at that point of time. For example, they will follow a king who they think has a higher probability of their loyalties do as well. If there are laws in such a society, they are malleable. The same laws can be interpreted differently at different points of time. Change is the only constant. Feminine civilizations, like Swadeep, are comfortable with contradictions. And the code for success in such a system? Unmistakably, Passion, Beauty and Freedom.' 'And no one way of life is better?' 'Obviously Both types of civilizations must exist. Because they balance each other.' 'How?' 'You see, a masculine civilization at its peak is honourable, consistent, reliable and spectacularly successful in an age suitable for its particular set of laws. There is order and society moves coherently in a preordained direction. Look at the Suryavanshis today. But when masculine civilizations decline, they cause horrible turmoil, becoming fanatical and rigid. They will attack those that are different, try to "convert" them to their "truth", which will lead to violence and chaos. This especially happens when an age changes. Change is difficult for the masculine. They will cling even more rigidly to their laws, even though those laws may be unsuitable for the new age. Masculine civilizations enforce order which is welcome when they are strong, but is suffocating when they decline. The Asuras, who were followers of the masculine way, had faced similar problems when their power started waning.' 'So when fanaticism causes rebellions born of frustration, the openness of the feminine brings a breath of fresh air.' 'Exactly. The feminine way incorporates all differences. People of varying faiths and belief can coexist in peace. Nobody tries to enforce their own version of the truth. There is a 
celebration of diversity and freedom, which brings forth renewed creativity and vigor causing tremendous benefits to society. The Devas, who were followers of the feminine way, brought in all this when they defeated the Asuras. But as iit happens with too much freedom, the feminine civilizations overreach into decadence, corruption and debauchery.' 'Then the people once again welcome the order of the masculine'. 'Yes. The feminine Deva way was in decline during Lord Ram's times. The country was corrupt, immoral and depraved. People clamored for order and civility. Lord Ram ushered that in as he created a new masculine way of life. Very intelligently, to prevent unnecessary rebellions, he never decried the Deva way. He just called his rule a new way of life: the Suryavanshi path.' (47-49 The Secret of the Nagas) In this long dialogue between Pandit and Shiva the modern reader is definitely convinced of ardhanarishwar philosophy. More scientific is the approach of Amish in analyzing the system of society and law of life and nature. No doubt. Trilogy is the fiction of new age.

\section{Rivers:}

The effort to join rivers or the thought to change the flow of the rivers is not a new plan. It occurred centuries back. Around 1900 BC. 'And when the Yamuna changed course from Meluha and started flowing into Swadweep, it met the Ganga at Prayag,'said Bhagirath. 'That would have made Prayag very important?' asked Shiva. 'Yes, My Lord. Just like Magadh, it became a crucial junction for river trade. And unlike Magadh, it was not bound by any treaty on its portage and trading charges. Any trader or kingdom wanting to settle or trade in the newly opened hinterlands of the Yamuna had to pay charges at Prayag. Its prosperity and power grew exponentially there were even rumours that they were planning to support Magadh in an Ashwamedh Yagna to challenge Ayodhya's suzerainty. But when my great grandfather lost the battle to the Suryavanshis and a dam was built on the Yamuna to turn the flow towards Meluha, Prayag's importance fell again. They have blamed Ayodhya ever since. They actually believe we purposely lost the war to give them a devastating blow.' (32, 33 The Secret of the Nagas) The effect of turning the river flow is clear in the novel. Shiva and Brahma's concern for the purity of the water of Ganga reminded of Modi's dreams in 21st century.

\section{Dream:}


In the Trilogy, Shiva dreams so many times. The dream analysis shows his fears, words of his inner mind which are possible in human. Amish, using these dreams at proper places have given the novel touch of reality or possibility. He is modern in reaching contemporary readers with such skills.

\section{Conclusion:}

Tripathi, the banker whose manuscript was famously rejected by 20- odd publishers, has become India's fastest selling author. The fiction also leads to many doubts and questions about chronology, concepts, relations, geography. As Indian philosophy perceives, Amish too presents individual psyche and society as a system that undergoes the process of self-creation and selfgeneration as opposed to a deliberate construction. The society is in constant interaction with its surroundings and any attempt to block the system would be to cut it off from the interactions that maintain it, thereby likely leading to its destruction. Amish gives reason for not destroying the knowledge of producing Somras scientifically. Today's elixir may prove poison tomorrow. Yesterday's poison may become elixir today. The work appeals to the souls of kids, who will enjoy courageous stances of young Ganesha and Karthik, feminists and women who will definitely appreciate the description of the valour of Sati. The youth, as well as old aged will obviously enjoy the adventurous journey, war against evil, new interpretations of God, Aum, Neelakantha, Somras, Brahmastra. Shiva in Shiva Trilogy is more human and ardent lover of Sati.

Women reader would worship Shiva for his love for his wife Sati; Tribals and downtrodden for his leadership and fearless war for their sake. The science and technology in producing somras, daiviastras and construction of temples, city system is so well imagined by Amish, that the reader may wonder of the possibility of it. The Trilogy appeals even modern adventurous mind as well as devotees of Lord Shiva. Shiva is not myth; a human being attaining lordship with extraordinary zeal to destroy evil, the production of somras and with concern for the purity of river water. Religion and Spirituality both are paths that lead to God or to that higher consciousness. Modern man is desperately trying to find succor from his personal and 
public angst and where codified religion seems to have failed, people have turned to New spirituality and to the many new age self- help books and popular spiritual fictions that seems to offer the succor they seek. As an end note, in a seeming paradox, religion too seems to make a comeback although in new forms.

\section{Works Cited:}

Tripathi, Amish. Immortals of Meluha. New Delhi: Westland Ltd, 2010. Print.

---. The Secret of the Nagas. New Delhi: Westland Ltd, 2012. Print.

---. The Oath of the Vayuputras. New Delhi: Westland Ltd., 2013. Print.

\section{Mr. Parthivkumar K. Patel Assistant Professor Parul University}

Email Id: parthivpatel56@gmail.com Mo: 9537370948 